\title{
Risk assessment of pollution with heavy metals in water and fish from River Nile, Egypt
}

\author{
Hala E. Ghannam ${ }^{1}$ \\ Received: 17 March 2021 / Accepted: 9 June 2021 / Published online: 25 June 2021 \\ (c) The Author(s) 2021
}

\begin{abstract}
The aim of this study is to investigate the level of contamination with metals ( $\mathrm{Fe}, \mathrm{Mn}, \mathrm{Zn}, \mathrm{Cu}$, and $\mathrm{Pb}$ ) in the Nile River at the great Cairo region. Samples of water and fish were collected seasonally from different sites along the investigated area. Physical and chemical parameters of the studied water samples such as temperature, transparency, electrical conductivity, $\mathrm{pH}$, BOD, and COD were measured. In aquatic ecosystems, heavy metal concentrations are monitored by detecting some indices like water pollution indices (WPI) and bioaccumulation factor (BAF). The results clarified that $\mathrm{Fe}, \mathrm{Pb}$, and $\mathrm{Mn}$ concentrations in water exceed the allowed limits set by WHO, 2011 in all sites while $\mathrm{Cu}$ and $\mathrm{Zn}$ are in allowed limits. While in fish muscle $\mathrm{Fe}$ and $\mathrm{Cu}$ are within the permissible limits set by FAO, 1992, but $\mathrm{Mn}, \mathrm{Zn}$ and $\mathrm{Pb}$ exceed the limits. Some of the metals like $\mathrm{Cu}, \mathrm{Fe}, \mathrm{Mn}, \mathrm{Ni}$ and $\mathrm{Zn}$ are essential for animals and plants while many other like $\mathrm{Pb}, \mathrm{Cd}, \mathrm{Cr}$ and $\mathrm{Co}$ are classed as nonessential metals. All values of $\mathrm{HI}$ were below 1 except for $\mathrm{Pb}$ in case of habitual fish eaters that give alarm to fish consumer.
\end{abstract}

Keywords Heavy metals $\cdot$ Water $\cdot$ Fish $\cdot$ Pollution $\cdot$ River Nile

\section{Introduction}

The River Nile is the main source of drinking water in Egypt; however, in recent years, huge quantities of industrial and agricultural wastes are discharged into the water body (Nada et al. 2016 and Al-Halani 2017). Pollution has a harmful effect on the water quality by decreasing dissolved oxygen and transparency of water; however, water temperature, electric conductivity, levels of nutrient salts, total dissolved solids and water alkalinity were increased (Ibrahim et al. 2013). In aquatic ecosystems, heavy metal concentrations are monitored by detecting their concentration in water (Ebrahimpour and Mushrifah 2008). Some of the metals like $\mathrm{Cu}, \mathrm{Fe}, \mathrm{Mn}$, $\mathrm{Ni}$ and $\mathrm{Zn}$ are essential for animals and plants while many other like $\mathrm{Pb}, \mathrm{Cd}, \mathrm{Cr}$ and $\mathrm{Co}$ have no known physiological activities (Aktar et al. 2010). Essential and nonessential metals have a great importance in ecotoxicology (Vinodhini and Narayanan 2008). According to (FAO 2013), Egypt is the eighth global aquaculture producer with about 986,820

Hala E. Ghannam

drhalaghannam@yahoo.com

1 Pollution Laboratory, Freshwater and Lakes Division, National Institute of Oceanography and Fisheries (NIOF), Cairo, Egypt tons in 2011. Fish consumption in Egypt rose from $8.5 \mathrm{~kg} /$ person/year in 1996 to $15.4 \mathrm{~kg}$ in 2008 and $20.8 \mathrm{~kg}$ in 2013 according to the General Authority for Fisheries Resource Development (GAFRD) (Eltholth et al. 2015 and Talab et al. 2016). Nile tilapia (Oreochromis niloticus) fish is one of the most common species in Egypt and preferred as food depending on its excellent rate of growth which is independent on low protein diets (Balirwa 1992). Fishes are good biomonitors for describing the quality of aquatic systems and for testing levels of metal pollution (Rashed 2001 and Lamas et al. 2007). Moreover, fish may accumulate metals in their flesh and throw them to human by eating these infected fish and causing different diseases (Al-Yousuf et al. 2000). Has-Schön et al. (2008) reported that accumulation in fish tissue is mainly result from concentrations of metals in water and also to environmental factors like exposure time, water temperature, $\mathrm{pH}$, oxygen concentration and dissolved organic carbon (Has-Schön et al. 2008). On the basis of the health effect of heavy metals on the human, this study aims to study the environmental and ecological pollution of heavy metals in River Nile using water and fish samples. For this purpose, the pollution indices including water pollution index (WPI), metal pollution index (MPI), bioaccumulation factor (BAF) and hazard index (HI) for fish are investigated. 


\section{Materials and methods}

\section{Study area}

Water and fish samples from the different sites along the area under investigation were collected seasonally (from autumn 2018 to summer 2019) at the mid-stream of each station as shown in Table 1.

\section{Collection and analysis of water sample}

Physical parameter of water sample (transparency, electrical conductivity and temperature) were measured in the field using a multi-probe portable meter (Model CRISON, Spain). While chemical parameter (BOD, COD and DO) and heavy metals were measured according to American public health association (APHA 1992) methods. Heavy metals ( $\mathrm{Fe}^{2+}$, $\mathrm{Mn}^{2+}, \mathrm{Zn}^{2+}, \mathrm{Cu}^{2+}$ and $\left.\mathrm{Pb}^{2+}\right)$ concentration were determined using Inductively Coupled Plasma Optical Emission Spectroscopy (ICP-OES), Varian Liberty Series II, Italy. The detection wavelengths were as follows; 324.752, 259.993, 259.610, 283.305 and 206.200 nm for $\mathrm{Cu}^{2+}, \mathrm{Fe}^{2+}, \mathrm{Mn}^{2+}$, $\mathrm{Pb}^{2+}$ and $\mathrm{Zn}^{2+}$, respectively.

\section{Collection and analysis of fish samples}

Nile tilapia fish samples (mean weights $200 \pm 57.7 \mathrm{~g}$, length $25.5 \pm 1.3 \mathrm{~cm}$ ) were collected seasonally from the same sites of water samples. They were washed with tap water to remove any adhering contaminants then preserved in a cooler at $4{ }^{\circ} \mathrm{C}$ to be transported to pollution laboratory, National Institute of Oceanography and Fisheries, El-Kanater El-Kairia Research Station, for carrying out the analysis. Fish muscle and liver were prepared for the analysis according to the method reported by (Mechea et al. 2010). ICP-OES (Varian liberty series II Italy) instrument was used to determine $\mathrm{Cu}^{+2}, \mathrm{Fe}^{2+}, \mathrm{Mn}^{2+}, \mathrm{Pb}^{2+}$ and $\mathrm{Zn}^{2+}$ as mentioned above.

\section{Water pollution index (WPI)}

It can be calculated for water samples as reported by (Caerio et al. 2005). So when PI $<1$ (there is no pollution), 1-2 (slightly affected), 2-3 (moderately affected), 3-5 (strongly affected) and $>5$ (seriously affected).

\section{Pollution load index (PLI)}

The pollution load index (PLI) in water of great Cairo region was proposed by (Tomlinson et al. 1980).

\section{Bioaccumulation factor}

Bioaccumulation factor (BAF) is the ratio of metal concentration in the organism to its concentration in the surrounding water and can be calculated for muscles and liver using equation illustrated by (Kalfakakour and Akrida-Demertzi 2000).

\section{Health risk assessment}

According to (USEPA 2000), hazard index (HI) is the ratio between the (ADD) average daily intake of specific chemical over lifetime to the (oral RFD) oral reference dose of metal as shown in the equation below. $\mathrm{HI}<1$ means that daily exposure has no adverse effects during person lifetime. $\mathrm{HI}>1$ it means daily exposure may have adverse effects during person lifetime (Pawelczyk 2013 and USEPA 2002).

\section{Statistical analysis}

All analyses were performed in triplicate. Statistical data analyses of the results were performed using WINDOWS 2010. The means of the replicates and evaluation of significant differences between different samples were determined using descriptive statistics and analysis of variance (ANOVA), respectively.

\section{Results and discussion}

\section{Physical and chemical parameters of water}

The results of physicochemical parameter of water at different sites of the investigated area are represented in (Fig. 1). Temperature shows maximum value at site I in summer, while minimum value recorded at site III during winter. (Ghannam and Talab 2009) reported that water temperature related to the sampling times, number of
Table 1 Different sites of the investigated area along River Nile

\begin{tabular}{lllll}
\hline Site & Name of sites & Latitude & Longitude & Type of pollution \\
\hline I & El-Tbeen district & $29^{\circ} 48^{\prime} 0^{\prime \prime} \mathrm{N}$ & $31^{\circ} 17^{\prime} 45^{\prime \prime} \mathrm{E}$ & Industrial activities \\
II & Manyal district & $30^{\circ} 0^{\prime} 54.56^{\prime \prime} \mathrm{N}$ & $31^{\circ} 13^{\prime} 17.62^{\prime \prime} \mathrm{E}$ & Domestic activities \\
III & El-Kanater El-Kairia City & $30^{\circ} 11^{\prime} 1^{\prime \prime} \mathrm{N}$ & $31^{\circ} 8^{\prime} 20^{\prime \prime} \mathrm{E}$ & Agricultural activities \\
\hline
\end{tabular}


sunshine and agree with the obtained results that highest values in summer and the lowest value was in winter season. Transparency shows minimum value during spring in site II, while maximum value recorded during autumn in site II. In spring, the increase in amount of phytoplankton lead to decrease in transparency, science transparency depends on the suspended solid and organic matter found in water body (Ghannam and Talab 2009). The same results obtained by (Olsen and Sommerfeld 1977) who stated that higher value of transparency is related to settling out of suspended particles to the bottom sediments that present during autumn season. For (EC), the lowest value was during spring at site III and the highest value was at site III during summer. The high values of EC may be attributed to the presence of large amount of organic and inorganic constituents that discharged into the Nile (Ghannam and Talab 2009). (Elewa and Mahdi 1988) recorded that decrease of EC during spring may be related to the increase of water level and the uptake of dissolved salt by phytoplankton (Siliem 1995). DO values showed
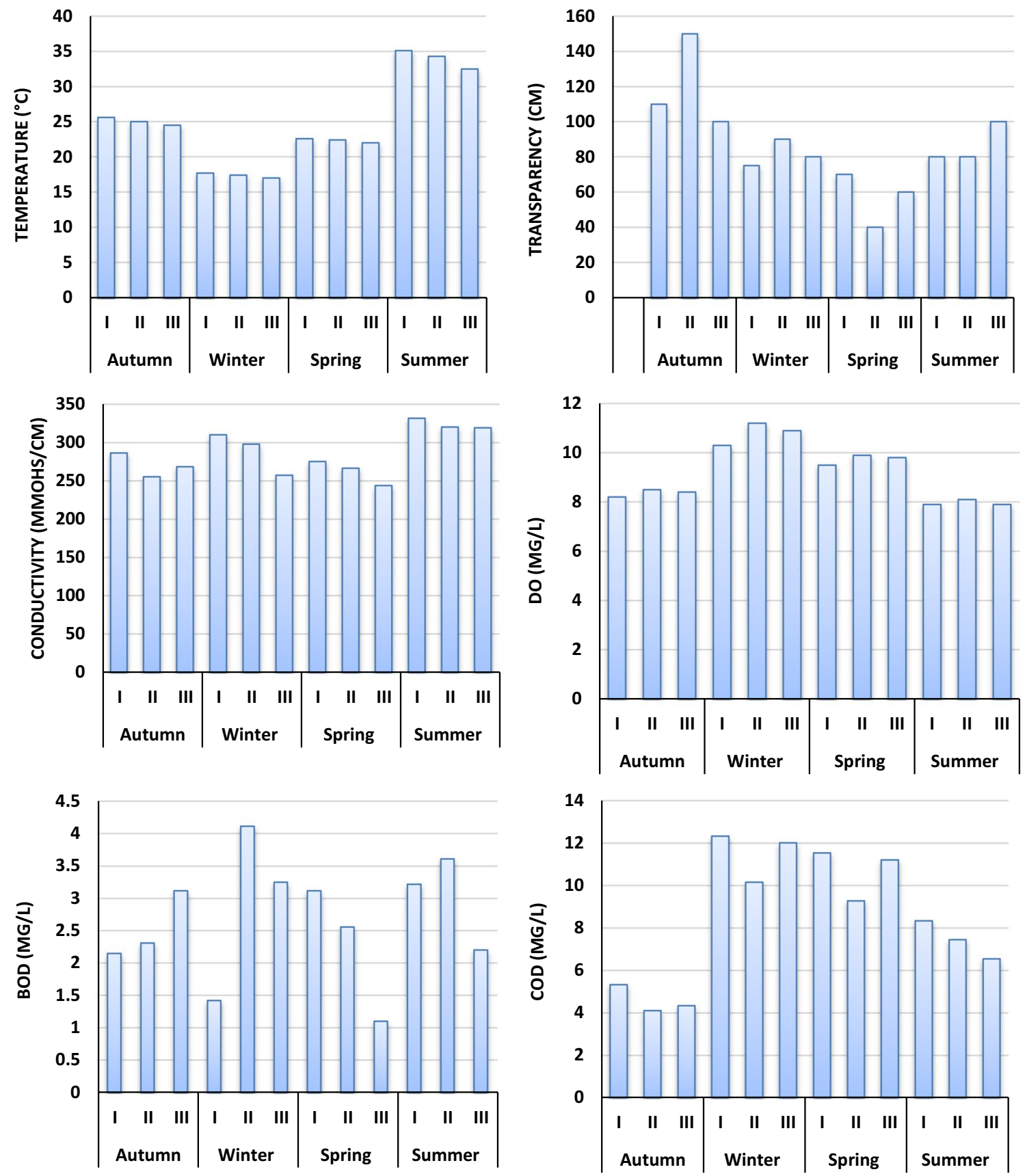

Fig. 1 Physicochemical parameter of water collected from different sites of the investigated area from autumn 2018 to summer 2019 
the order: winter $>$ spring $>$ autumn $>$ summer were highest value was in winter and the lowest was in summer. The same results obtained by (Ghannam and Talab 2009) who found that temperature, $\mathrm{pH}$ and photosynthesis activity have a strong effect on dissolved oxygen. Biochemical oxygen demand (BOD) showed maximum value at site II during winter and minimum was observed at site III during spring. The values obtained during summer and autumn may be depend on the presence of dead microorganism at the bottom layer of water that not able to make aerobic biochemical oxidation of wastes especially at low oxygen content (Siliem 1995). While the increase in winter value may be depend on the wind prevailing mixing water layers in Nile due to decline in depth that increasing the biological activity in aquatic system (Ghannam and Talab 2009). In chemical oxygen demand, the maximum value was at site I during winter while minimum value was at site II during autumn and the order was winter $>$ spring $>$ summer $>$ autumn. Egyptian ministry of health gives maximum limits for COD ranged from 10 to $15 \mathrm{mg} / \mathrm{L}$ in Nile water, also (Beger 1974) reported that, good water contains organic matter not more than $12 \mathrm{mg} / \mathrm{L}$ and that expressed as oxygen consumed by permanganate. El-Sherbini (1996) determined the COD values in River Nile from Aswan to El-Kanater El-Kairia and found that the values were in range $5-25 \mathrm{mg} / \mathrm{L}$ and $65 \%$ of measured samples were less $10 \mathrm{mg} / \mathrm{L}$.

\section{Heavy metals in water}

The maximum value for iron was observed at site I during autumn, and the lowest value was at site II during summer. For $\mathrm{Cu}$, the maximum value was observed at site III during spring, and the minimum value was recorded at site II during summer. The maximum value for $\mathrm{Zn}$ was at site I during winter, and the minimum value was recorded at site II during summer. For $\mathrm{Pb}$, the maximum value was recorded

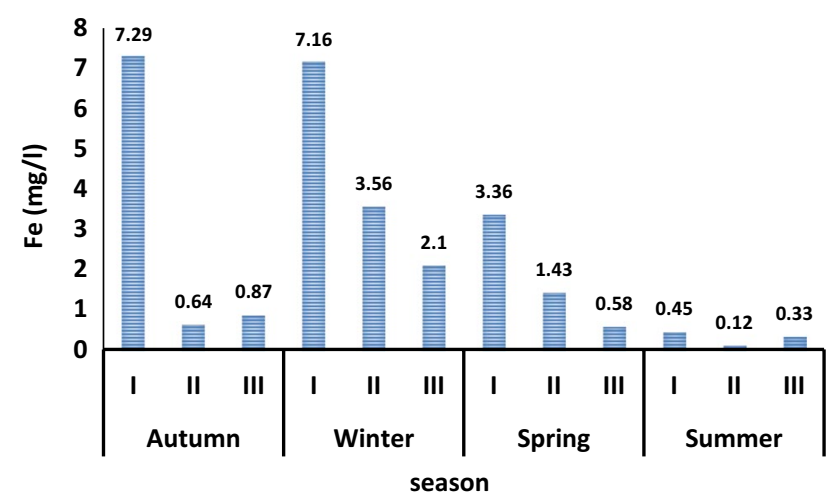

Fig. 2 Fe concentration (mg/L) in water samples from autumn 2018 to summer 2019 along the investigated area at site I during winter, while the minimum value was at site III during summer. Finally, Mn maximum value was at site II during spring, also minimum value was at site II during summer (Figs. 2, 3, 4, 5, 6). According to Egyptian drinking water quality standards (2007) limit and (WHO 2011), the allowed concentration of $\mathrm{Fe}, \mathrm{Pb}, \mathrm{Mn}$, and $\mathrm{Cu}$ are $0.3,0.01,0.1$ and $2.0 \mathrm{mg} / \mathrm{L}$, respectively. From (Figs. 2, $3,4,5,6)$ it is shown that $\mathrm{Fe}, \mathrm{Pb}$, and Mn concentrations exceed the allowed limits in all sites which may cause a negative health effect (Kempster et al. 1997), while $\mathrm{Cu}$ and $\mathrm{Zn}$ are in allowed limits. The higher concentrations of Mn during winter and spring season may be related to the drought period and the extraction of manganese from dead aquatic plants that become easy as a result of decreasing in water level with settling in water current beside the dissolution of sediment manganese and its presence water during spring (Ghannam et al. 2014). High values of $\mathrm{Cu}$ during spring may be depend on the high evaporation rate and increase of air and water temperatures or the release of copper from sediment to surrounding water (Warren and Zimmerman 1994). (Adelaide et al. 2000) recorded

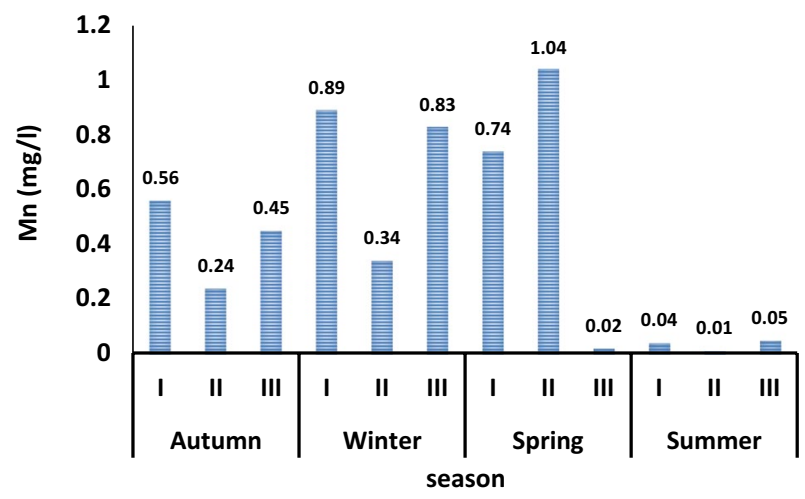

Fig. 3 Mn concentration (mg/L) in water samples from autumn 2018 to summer 2019 along the investigated area

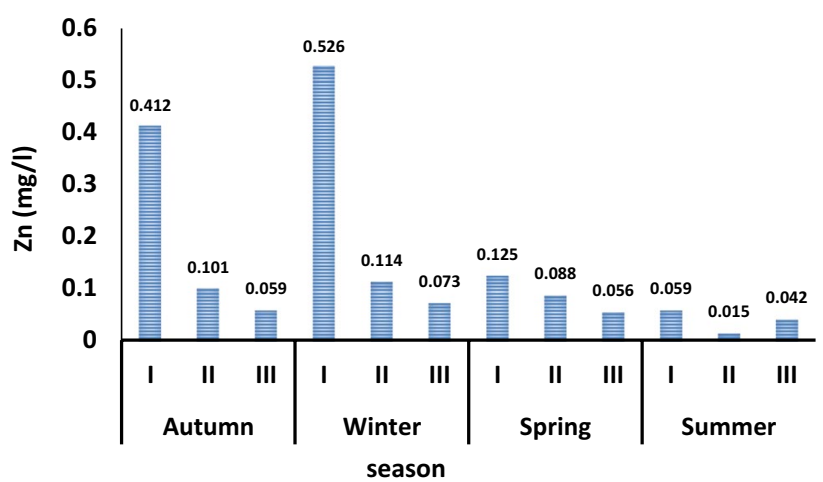

Fig. $4 \mathrm{Zn}$ concentration (mg/L) in water samples from autumn 2018 to summer 2019 along the investigated area 


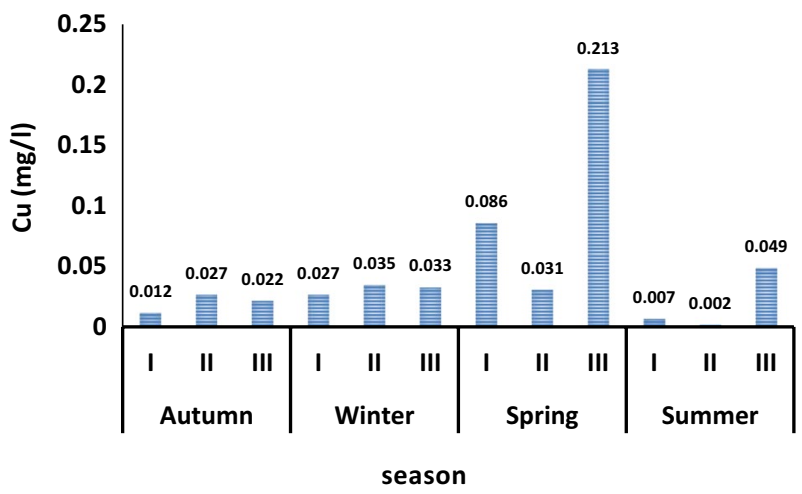

Fig. $5 \mathrm{Cu}$ concentration $(\mathrm{mg} / \mathrm{L})$ in water samples from autumn 2018 to summer 2019 along the investigated area

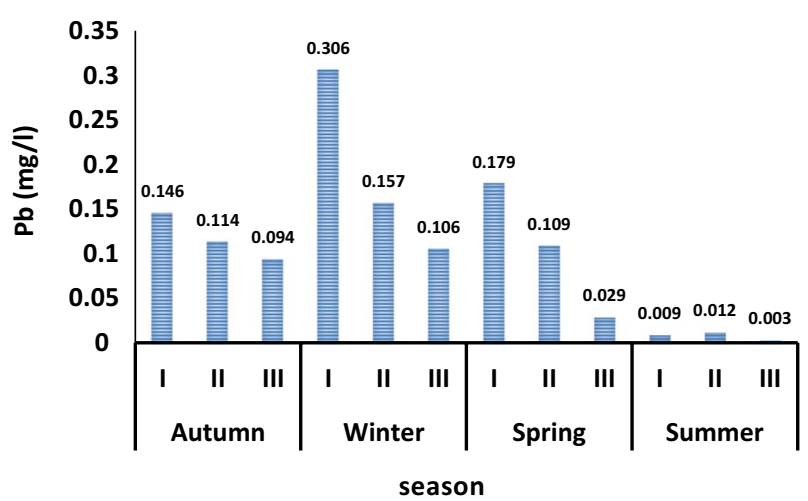

Fig. $6 \mathrm{~Pb}$ concentration $(\mathrm{mg} / \mathrm{L})$ in water samples from autumn 2018 to summer 2019 along the investigated area

that the factors that causing highest $\mathrm{Zn}$ values in winter were drought period and decrease in zinc sorption at low temperature. Also, $\mathrm{Pb}$ higher concentrations during winter and spring seasons may be related to drought period while low $\mathrm{Pb}$ concentrations during summer is come from the formation of $\mathrm{Fe}(\mathrm{OH})_{3}$ which act as adsorbent (Foster and Charlesworth 1996). Also, $\mathrm{Pb}$ is easily dissolved in water because it is weakly associated with air particles (Badr et al. 2006).

\section{Heavy metals in fish organs}

Concentration of heavy metals in muscles and liver of (Oreochromis niloticus) is recorded in Table 2. In fish muscle, the maximum value of $\mathrm{Fe}$ (21.8) was recorded at site I during spring while for Mn was $(43.0 \mu \mathrm{g} / \mathrm{g}$ dry wt) at site III during summer. For $\mathrm{Zn}$ the value was $(51.11 \mu \mathrm{g} / \mathrm{g}$ dry wt) at site II during spring where, in cu was $(4.9 \mu \mathrm{g} / \mathrm{g}$ dry wt) at site I in summer, finally for $\mathrm{Pb}$ was $(2.12 \mu \mathrm{g} / \mathrm{g}$ dry wt) at site I during winter. While in liver, the maximum values were $(94,59,65,6.34$ and
$6.39 \mu \mathrm{g} / \mathrm{g}$ dry wt) for (Fe, $\mathrm{Mn}, \mathrm{Zn}, \mathrm{Cu}$ and $\mathrm{Pb})$, respectively. Accumulation of heavy metals in muscles is lower than liver because muscles have low level of binding proteins and enzymatic activities (Papagiannis et al. 2004). According to (FAO 1992), the results for fish muscle indicate that $\mathrm{Fe}$ and $\mathrm{Cu}$ metals are within the permissible limits but $\mathrm{Mn}, \mathrm{Zn}$ and $\mathrm{Pb}$ exceed the limits.

\section{Water pollution index (WPI)}

Water pollution index was calculated for each metal individually ( $\mathrm{Fe}, \mathrm{Mn}, \mathrm{Cu}, \mathrm{Pb}$ and $\mathrm{Zn}$ ). According to the results shown in (Fig. 7), the sites are suffering from different kinds of heavy metal contamination. In almost sites, the effects were $>5$ which means seriously affected with heavy metal for aquatic life. But site III was in the range 3-5 for $\mathrm{Fe}$ and $\mathrm{Pb}$. As reported by (Caerio et al. 2005) in water samples when WPI lower than 1 , this indicates that there is no pollution found in this site and by increasing the WPI value from $1-2$ mean, site is slightly affected by pollution. From 2 to 3 moderately affected, from 3 to 5 strongly affected and $>5$ seriously affected. In almost site of this study, the values were higher than 5 which give an indication that these sites are seriously affected by different sources of pollution.

Pollution load index for the different sites at different seasons is shown in (Fig. 8). At site (I), the values ware ranged between 2.1 and 2.6 and the maximum value was in spring season. At site (II), the values ranged from 2.03 to 2.14 and the highest was in winter. Lastly, at site (III), the values were between 1.26 and 2.07. The calculations indicated that all results are closely and greater than 1 which give an indication to the progressive deterioration of estuarine quality. If the index $=0$ this indicate perfection, index $=1$ means there is only baseline levels of pollutants are found, index $>1$ means progressive deterioration of estuarine quality (Tomlinson et al. 1980). The obtained results of PLI give benefit information about the quality of aquatic system in this area and help the decision-maker to solve this pollution problem (Goher et al. 2014).

\section{Bioaccumulation factor}

Bioaccumulation factor of heavy metals ( $\mathrm{Fe}, \mathrm{Mn}, \mathrm{Zn}, \mathrm{Cu}$, and $\mathrm{Pb}$ ) was determined in flesh and liver of Nile Tilapia (Tables 3, 4). The results showed that the highest value for Fe was (122.60) and for Mn was (1660.00) for Zn (2747.33) and for $\mathrm{Cu}$ (1835.00) was recorded at site (II) during summer. The exception was for $\mathrm{Pb}$ which recorded (211.11) at site (I) during summer also. The obtained results for liver showed higher values than obtained by muscle but the values showed the same trend obtained by muscle. The maximum values of

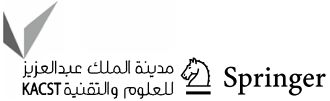


Table 2 Heavy metals concentration in fish muscles and liver $(\mu \mathrm{g} / \mathrm{g}$ dry $\mathrm{wt})$ from autumn 2018 to summer 2019 at sites I, II, III

\begin{tabular}{|c|c|c|c|c|c|c|c|}
\hline Season & Site & Fish organ & $\begin{array}{l}\mathrm{Fe} \\
(\mu \mathrm{g} / \mathrm{g})\end{array}$ & $\begin{array}{l}\text { Mn } \\
(\mu \mathrm{g} / \mathrm{g})\end{array}$ & $\begin{array}{l}\mathrm{Zn} \\
(\mu \mathrm{g} / \mathrm{g})\end{array}$ & $\begin{array}{l}\mathrm{Cu} \\
(\mu \mathrm{g} / \mathrm{g})\end{array}$ & $\begin{array}{l}\mathrm{Pb} \\
(\mu \mathrm{g} / \mathrm{g})\end{array}$ \\
\hline \multirow[t]{6}{*}{ Autumn } & \multirow[t]{2}{*}{ I } & Muscle & 11 & 16.01 & 33.01 & 2.32 & 2.02 \\
\hline & & Liver & 28 & 19.62 & 44.21 & 3.54 & 5.70 \\
\hline & \multirow[t]{2}{*}{ II } & Muscle & 7.1 & 12 & 20.22 & 4.64 & 0.93 \\
\hline & & Liver & 15.32 & 20.21 & 33.12 & 6.34 & 5.05 \\
\hline & \multirow[t]{2}{*}{ III } & Muscle & 10.56 & 11.22 & 12 & 4.65 & 0.75 \\
\hline & & Liver & 12.34 & 19.34 & 34.09 & 6.01 & 3.22 \\
\hline \multirow[t]{6}{*}{ Winter } & \multirow[t]{2}{*}{ I } & Muscle & 8.1 & 9.29 & 23.68 & 2.12 & 2.12 \\
\hline & & Liver & 64.75 & 16 & 37 & 3.55 & 4.09 \\
\hline & \multirow[t]{2}{*}{ II } & Muscle & 16.3 & 17.23 & 45.32 & 1.64 & 1.07 \\
\hline & & Liver & 21.72 & 22 & 46.45 & 3.59 & 4.12 \\
\hline & \multirow[t]{2}{*}{ III } & Muscle & 12.01 & 7.9 & 22.21 & 1.58 & 0.90 \\
\hline & & Liver & 21.50 & 18.89 & 40.34 & 5.98 & 3.19 \\
\hline \multirow[t]{6}{*}{ Spring } & \multirow[t]{2}{*}{ I } & Muscle & 21.80 & 18 & 43.22 & 2.01 & 1.76 \\
\hline & & Liver & 94.00 & 28.12 & 65 & 8.31 & 6.32 \\
\hline & \multirow[t]{2}{*}{ II } & Muscle & 18.00 & 41.43 & 51.11 & 2.87 & 1.23 \\
\hline & & Liver & 19.71 & 59.00 & 55.03 & 3.34 & 5.29 \\
\hline & \multirow[t]{2}{*}{ III } & Muscle & 10.00 & 7.43 & 21.33 & 1.58 & 0.81 \\
\hline & & Liver & 17.60 & 31.31 & 51.31 & 2.46 & 4.31 \\
\hline \multirow[t]{6}{*}{ Summer } & \multirow[t]{2}{*}{ I } & Muscle & 15.30 & 11.01 & 41 & 4.90 & 1.90 \\
\hline & & Liver & 66.00 & 14.9 & 52.2 & 6.00 & 6.39 \\
\hline & \multirow[t]{2}{*}{ II } & Muscle & 14.70 & 16.6 & 41.21 & 3.67 & 1.02 \\
\hline & & Liver & 35.10 & 31.03 & 47.34 & 4.02 & 6.21 \\
\hline & \multirow[t]{2}{*}{ III } & Muscle & 13.70 & 43.00 & 22.00 & 2.24 & 0.32 \\
\hline & & Liver & 18 & 50.00 & 51.04 & 3.56 & 4.27 \\
\hline MPL & & & 30 & 30 & 50 & 30 & 2 \\
\hline
\end{tabular}

$M P L$ the maximum permissible limit of heavy metals in fish muscles ( $\mu \mathrm{g} / \mathrm{g}$ dry wt) according to (FAO 1992)

$\mathrm{Fe}, \mathrm{Mn}, \mathrm{Zn}$ and $\mathrm{Cu}$ were recorded at site (II) and for $\mathrm{Pb}$ were at site (I) during summer. Variations in ability of organs for accumulation of metal showed that the concentrations of the metals in the organs were in the order of liver $>$ flesh for all metals. The bioaccumulation of metals in liver may be due to its function of metabolism (Zhao et al. 2012), means, chemical processes that happen inside a living organism to keep life. High level of different heavy metals in liver also due to natural protein binding such as Metallothioneins (Gorar et al. 2012). Liver considers as store for metals, redistribution, and detoxification (Amiard et al. 2006). The same results of high level of metals in liver were studied by (Eisler 2010; Dural et al. 2007 and El-Moselhy 2000).

\section{Human risk assessment}

Depending on the values of $\mathrm{HI}$ at mean ingestion rate for normal adult no health effect occurred for all metals because all values of $\mathrm{HI}$ were below 1. But for habitual, values for $\mathrm{Fe}, \mathrm{Mn}$, $\mathrm{Zn}$ and $\mathrm{Cu}$ were below 1 except $\mathrm{Pb}$, show some exceptions at different seasons in the three sites. But, some HI values especially lead in case of habitual fish eaters at the three sites were higher than other values along the studied sites showing alarming values Tables 5 and 6. Generally, HI values for each investigated metal do not have unacceptable threats at mean ingestion rate for muscle and liver tissues (Pawelczyk 2013 and USEPA 2002).

\section{Conclusion}

This work concerned with the quality of water and fish in three sites which represent different sources of pollution along the River Nile. Nile tilapia has been used as a bio-indicator to monitor metal pollution by measuring their concentration in flesh and liver and the results indicate lower concentration in flesh than muscle. The results showed different accumulation degrees at the studied sites, where site I in El-Tbeen district that represent the industrial pollution has the highest accumulation extend. The results found that the different site suffering from metal pollution and the order was site I $>$ site II $>$ site III. 
Fig. 7 Water Pollution Index of the measured metals in water collected from investigated area. Pollution load Index
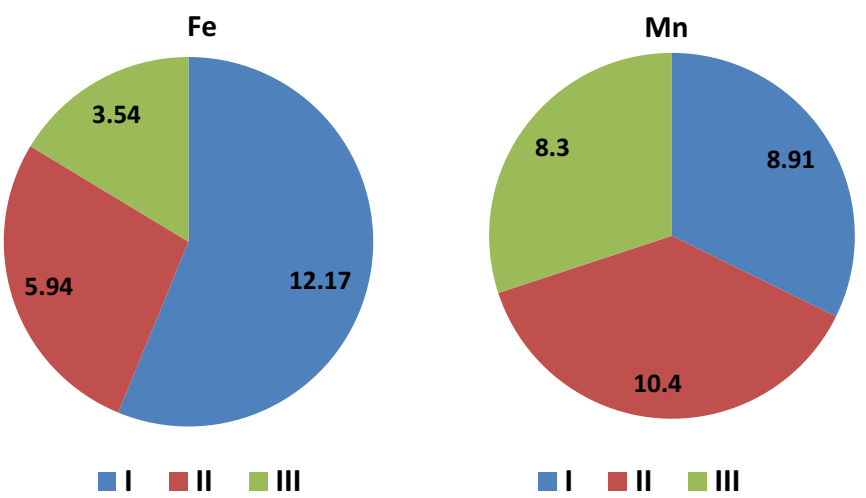

ロ I II $\square$ III

Zn
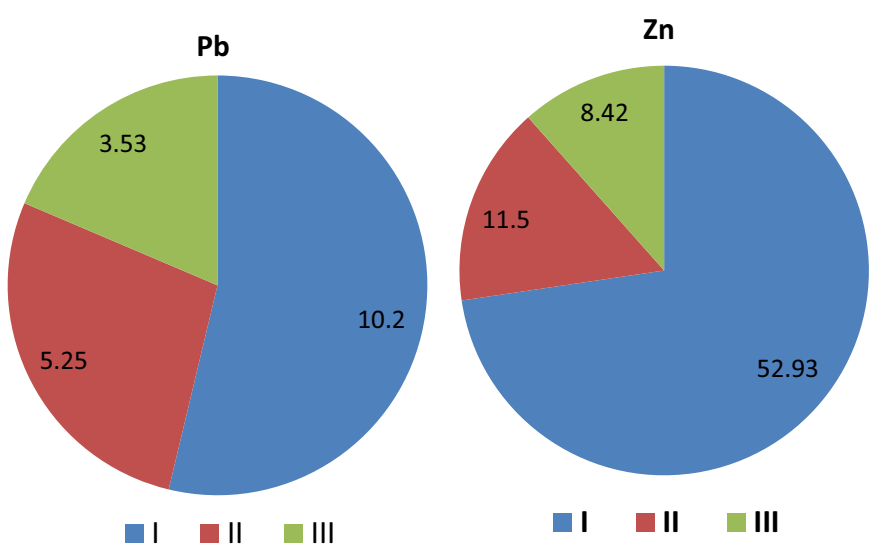

Table 3 Bioaccumulation factor $(\mathrm{L} / \mathrm{Kg})$ of different heavy metals in flesh of Nile Tilapia at different station from autumn 2018 to summer 2019

\begin{tabular}{|c|c|c|c|c|c|c|}
\hline Season & Site & $\mathrm{Fe}$ & Mn & $\mathrm{Zn}$ & $\mathrm{Cu}$ & $\mathrm{Pb}$ \\
\hline \multirow[t]{3}{*}{ Autumn } & I & 1.51 & 28.59 & 80.12 & 193.33 & 13.84 \\
\hline & II & 11.09 & 50.00 & 200.20 & 171.85 & 8.16 \\
\hline & III & 12.14 & 24.91 & 203.39 & 211.36 & 7.98 \\
\hline \multirow[t]{3}{*}{ Winter } & I & 1.13 & 10.44 & 45.02 & 78.52 & 6.93 \\
\hline & II & 4.58 & 50.68 & 397.54 & 46.86 & 6.82 \\
\hline & III & 5.72 & 9.52 & 304.25 & 47.88 & 8.49 \\
\hline \multirow[t]{3}{*}{ Spring } & I & 6.49 & 24.32 & 345.76 & 23.37 & 9.83 \\
\hline & II & 12.59 & 39.84 & 580.80 & 92.58 & 11.28 \\
\hline & III & 17.24 & 371.50 & 380.89 & 7.42 & 27.93 \\
\hline \multirow[t]{3}{*}{ Summer } & I & 34.00 & 275.25 & 694.92 & 700.00 & 211.11 \\
\hline & II & 122.50 & 1660.00 & 2747.33 & 1835.00 & 85.00 \\
\hline & III & 41.52 & 860.00 & 523.81 & 45.71 & 106.67 \\
\hline
\end{tabular}

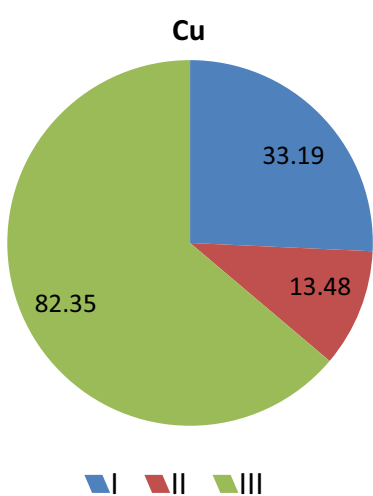

a all aII 
Table 4 Bioaccumulation factor $(\mathrm{L} / \mathrm{Kg})$ of different heavy metals in liver of Nile Tilapia at different station from autumn 2018 to summer 2019

\begin{tabular}{|c|c|c|c|c|c|c|}
\hline Season & Site & $\mathrm{Fe}$ & $\mathrm{Mn}$ & $\mathrm{Zn}$ & $\mathrm{Cu}$ & $\mathrm{Pb}$ \\
\hline \multirow[t]{3}{*}{ Autumn } & I & 3.84 & 35.04 & 107.31 & 295.00 & 39.04 \\
\hline & II & 23.94 & 84.21 & 327.92 & 234.81 & 44.30 \\
\hline & III & 14.18 & 42.98 & 577.80 & 273.18 & 34.26 \\
\hline \multirow[t]{3}{*}{ Winter } & I & 9.04 & 17.98 & 70.34 & 131.48 & 13.37 \\
\hline & II & 6.10 & 64.71 & 407.46 & 102.57 & 26.24 \\
\hline & III & 10.24 & 22.76 & 552.60 & 181.21 & 30.09 \\
\hline \multirow[t]{3}{*}{ Spring } & I & 27.98 & 38.00 & 520.00 & 96.63 & 35.31 \\
\hline & II & 13.78 & 56.73 & 625.34 & 109.68 & 48.53 \\
\hline & III & 30.34 & 1556.50 & 916.25 & 11.55 & 148.62 \\
\hline \multirow[t]{3}{*}{ Summer } & I & 146.67 & 372.50 & 884.75 & 857.14 & 710.00 \\
\hline & II & 292.50 & 3103.00 & 3156.00 & 2010.00 & 517.50 \\
\hline & III & 54.55 & 1000.00 & 1215.24 & 72.65 & 1423.33 \\
\hline
\end{tabular}

Table 5 Hazard index for muscle of $O$. niloticus at mean ingestion rate $(0.0312 \mathrm{~kg} / \mathrm{day})$ and subsistence ingestion rate $(0.1424 \mathrm{~kg} / \mathrm{day})$

\begin{tabular}{|c|c|c|c|c|c|c|c|c|c|c|c|}
\hline \multirow[t]{2}{*}{ Site } & \multirow[t]{2}{*}{ Season } & \multicolumn{2}{|l|}{$\mathrm{Fe}$} & \multicolumn{2}{|l|}{$\mathrm{Mn}$} & \multicolumn{2}{|l|}{$\mathrm{Cu}$} & \multicolumn{2}{|l|}{$\mathrm{Zn}$} & \multicolumn{2}{|l|}{$\mathrm{Pb}$} \\
\hline & & Normal & Habitual & Normal & Habitual & Normal & Habitual & Normal & Habitual & Normal & Habitual \\
\hline \multirow[t]{4}{*}{ I } & Autumn & 0.007 & 0.032 & 0.051 & 0.233 & 0.026 & 0.103 & 0.049 & 0.224 & 0.300114 & $1.369752^{*}$ \\
\hline & Winter & 0.005 & 0.021 & 0.038 & 0.174 & 0.052 & 0.206 & 0.030 & 0.137 & 0.138171 & 0.630629 \\
\hline & Spring & 0.007 & 0.031 & 0.036 & 0.163 & 0.052 & 0.206 & 0.018 & 0.081 & 0.111429 & 0.508571 \\
\hline & Summer & 0.005 & 0.024 & 0.030 & 0.135 & 0.024 & 0.094 & 0.035 & 0.161 & 0.314971 & $1.437562^{*}$ \\
\hline \multirow[t]{4}{*}{ II } & Autumn & 0.010 & 0.047 & 0.055 & 0.250 & 0.018 & 0.073 & 0.067 & 0.307 & 0.158971 & 0.725562 \\
\hline & Winter & 0.008 & 0.035 & 0.025 & 0.115 & 0.018 & 0.070 & 0.033 & 0.151 & 0.133714 & 0.610286 \\
\hline & Spring & 0.014 & 0.063 & 0.057 & 0.262 & 0.022 & 0.089 & 0.064 & 0.293 & 0.261486 & $1.193448^{*}$ \\
\hline & Summer & 0.011 & 0.052 & 0.132 & 0.602 & 0.032 & 0.127 & 0.076 & 0.347 & 0.182743 & 0.834057 \\
\hline \multirow[t]{4}{*}{ III } & Autumn & 0.006 & 0.029 & 0.024 & 0.108 & 0.018 & 0.070 & 0.032 & 0.145 & 0.120343 & 0.549257 \\
\hline & Winter & 0.010 & 0.044 & 0.035 & 0.160 & 0.055 & 0.217 & 0.061 & 0.278 & 0.282286 & $1.288381^{*}$ \\
\hline & Spring & 0.009 & 0.043 & 0.053 & 0.241 & 0.041 & 0.163 & 0.061 & 0.279 & 0.151543 & 0.691657 \\
\hline & Summer & 0.009 & 0.040 & 0.137 & 0.625 & 0.025 & 0.099 & 0.033 & 0.149 & 0.047543 & 0.21699 \\
\hline
\end{tabular}

*means: The values of Hazard index for muscle of $O$. niloticus $>1$

Table 6 Hazard index for liver of $O$. niloticus at mean ingestion rate $(0.0312 \mathrm{~kg} /$ day $)$ and subsistence ingestion rate $(0.1424 \mathrm{~kg} / \mathrm{day})$

\begin{tabular}{|c|c|c|c|c|c|c|c|c|c|c|c|}
\hline \multirow[t]{2}{*}{ Site } & \multirow[t]{2}{*}{ Season } & \multicolumn{2}{|l|}{$\mathrm{Fe}$} & \multicolumn{2}{|l|}{$\mathrm{Mn}$} & \multicolumn{2}{|l|}{$\mathrm{Cu}$} & \multicolumn{2}{|l|}{$\mathrm{Zn}$} & \multicolumn{2}{|l|}{$\mathrm{Pb}$} \\
\hline & & Normal & Habitual & Normal & Habitual & Normal & Habitual & Normal & Habitual & Normal & Habitual \\
\hline \multirow[t]{4}{*}{ I } & Autumn & 0.18 & 0.08 & 0.06 & 0.29 & 0.04 & 0.18 & 0.07 & 0.30 & 0.85 & $3.87 *$ \\
\hline & Winter & 0.10 & 0.04 & 0.06 & 0.29 & 0.07 & 0.32 & 0.05 & 0.22 & 0.75 & $3.42 *$ \\
\hline & Spring & 0.08 & 0.04 & 0.06 & 0.28 & 0.07 & 0.31 & 0.05 & 0.23 & 0.48 & $2.18^{*}$ \\
\hline & Summer & 0.41 & 0.19 & 0.05 & 0.23 & 0.04 & 0.18 & 0.05 & 0.25 & 0.61 & $2.77^{*}$ \\
\hline \multirow[t]{4}{*}{ II } & Autumn & 0.14 & 0.06 & 0.07 & 0.32 & 0.04 & 0.18 & 0.07 & 0.31 & 0.61 & $2.79 *$ \\
\hline & Winter & 0.14 & 0.06 & 0.06 & 0.27 & 0.07 & 0.30 & 0.06 & 0.27 & 0.47 & $2.16^{*}$ \\
\hline & Spring & 0.60 & 0.27 & 0.09 & 0.41 & 0.09 & 0.42 & 0.10 & 0.44 & 0.94 & $4.29 *$ \\
\hline & Summer & 0.13 & 0.06 & 0.19 & 0.86 & 0.04 & 0.17 & 0.08 & 0.37 & 0.79 & $3.59^{*}$ \\
\hline \multirow[t]{4}{*}{ III } & Autumn & 0.11 & 0.05 & 0.10 & 0.45 & 0.03 & 0.13 & 0.08 & 0.35 & 0.64 & $2.92 *$ \\
\hline & Winter & 0.42 & 0.19 & 0.05 & 0.22 & 0.07 & 0.31 & 0.08 & 0.35 & 0.95 & $4.33^{*}$ \\
\hline & Spring & 0.22 & 0.10 & 0.10 & 0.45 & 0.04 & 0.20 & 0.07 & 0.32 & 0.92 & $4.21 *$ \\
\hline & Summer & 0.11 & 0.05 & 0.16 & 0.73 & 0.04 & 0.18 & 0.08 & 0.35 & 0.63 & $2.90 *$ \\
\hline
\end{tabular}

*means: The values of Hazard index for liver of $O$. niloticus $>1$ 


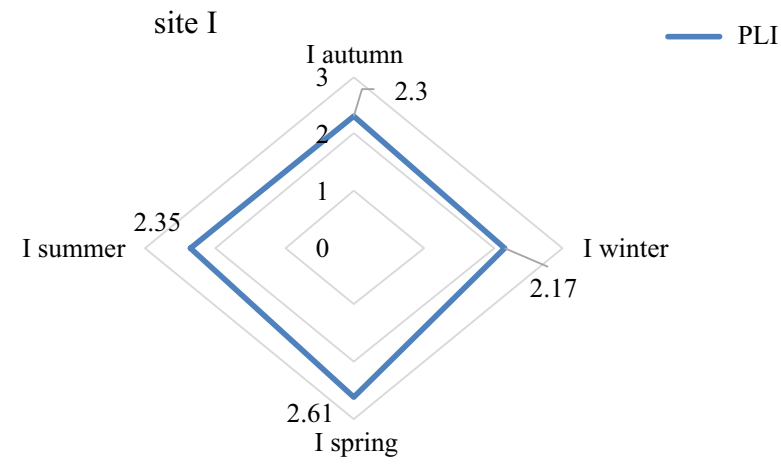

Site II
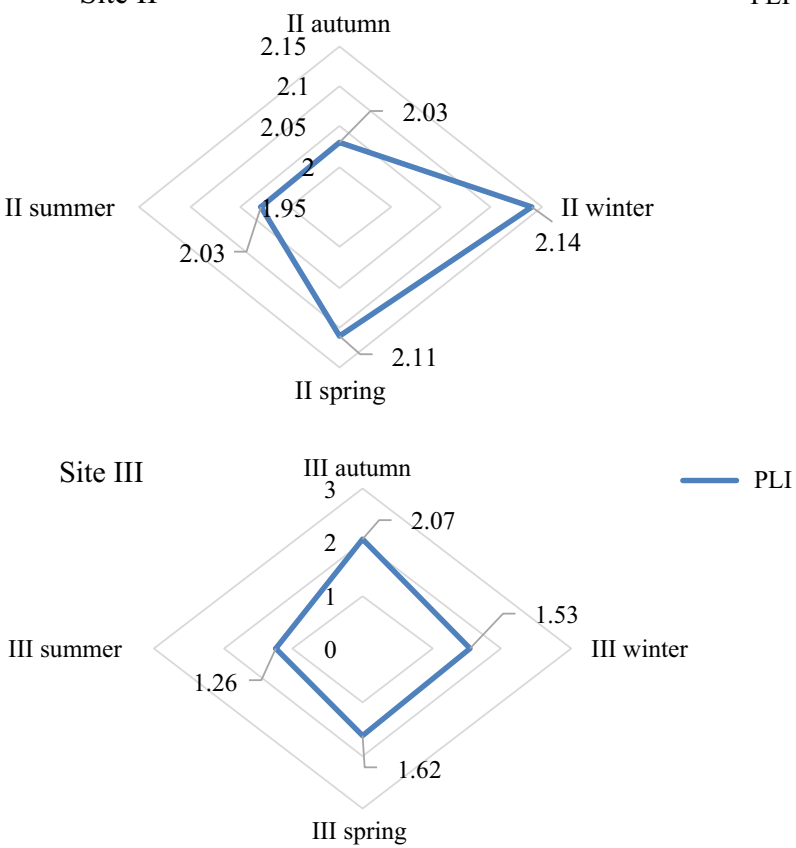

Fig. 8 Pollution Load index (PLI) in water at different sites (I, II, III) from autumn 2018 to summer 2019

Funding No funding was received for conducting this study.

Data availability Data will be made available upon request.

\section{Declarations}

Conflict of interest The author declares that she has no known competing financial interests or personal relationships that could have appeared to influence the work reported in this paper.

Open Access This article is licensed under a Creative Commons Attribution 4.0 International License, which permits use, sharing, adaptation, distribution and reproduction in any medium or format, as long as you give appropriate credit to the original author(s) and the source, provide a link to the Creative Commons licence, and indicate if changes were made. The images or other third party material in this article are included in the article's Creative Commons licence, unless indicated otherwise in a credit line to the material. If material is not included in the article's Creative Commons licence and your intended use is not permitted by statutory regulation or exceeds the permitted use, you will need to obtain permission directly from the copyright holder. To view a copy of this licence, visit http://creativecommons.org/licenses/by/4.0/.

\section{References}

Adelaide M, Olivera A, Gilles R, Pinte G, Ayrault S, Toulhoat P (2000) Study of water and sediment interaction in the Dasvelas River Berazil: major and trace elements. ISSN 0378-4738. Water SA 26(2): 255-274

Aktar MW, Paramasivam M, Ganguly M, Purkait S, Sengupta D (2010) Assessment and occurrence of various heavy metals in surface water of Ganga River around Kolkata: a study for toxicity and ecological impact. Environ Monitor Assess 160(1-4):207-213

Al-Halani, A Ali (2017) Ecological Studies on Effects of Water Quality on some Teleosts: African Catfish (Clarias gariepinus) and Nile Tilapia (Oreochromis niloticus) from different Freshwater Habitats. Ph. D. Thesis. Faculty of Science, Mansoura University

Al-Yousuf MH, El-Shahawi MS, Al-Ghais SM (2000) Trace metals in liver, skin and muscle of Lethrinus lentjan fish species in relation to body length and sex. Sci Total Environ 256:87-94

Amiard J, Amiardtriquet C, Barka S, Pellerin J, Rainbow P (2006) Metallothioneins in aquatic invertebrates: their role in metal detoxification and their use as biomarkers. Aquatic Toxicology 76(2):160-202

APHA (1992) Standard Methods for the examination of water and wastewater 18th edn., American Public Health Association, washington

Badr MH, Elewa A, Shehata MB, Mohamed LF, Abdelaziz GS (2006) Studies on the effect of El-Rahawy Drain on the River Nile water pollution by trace metals and major cations at El-Kanater ElKhyria area under the effect of seasonal variation. J Bull Environ Res 9:35-54

Balirwa JS (1992) The evaluation of the fishers of Oreochramis nicloticus (species: cchidae) in lake Victoria. Hydrobiologia 232:85-89

Beger H (1974) The values and the importance of limiting concentration in determining the hygienic quality of water. Part(I) KI Mtt Ver Wasser Buden and Lufthyg. 18, 15. Water pollution abs v (Dec 1943)

Caerio S, Costa MH, Ramos TB, Fernandes F, Silveria N, Coimbra A, Mederios G, Painho M (2005) Assessing heavy metal contamination in sado Estuarry Sedimint: an index analysis approach. Ecolog Indicators 5:151-169

Dural M, Göksu MZ, Özak AA (2007) Investigation of heavy metal levels in economically important fish species captured from the Tuzla lagoon. Food Chem 102(1):415-421

Ebrahimpour M, Mushrifah I (2008) Heavy metal concentrations in water and sediments in Tasik Chini a freshwater lake Malaysia. Environ Monit Assess 141:297-307

Egyptian Drinking Water Quality Standards (2007) Ministry of health population decision no (458)

Eisler R (2010) Compendium of trace metals and marine biota 2 Vertebrates. Elsevier Amsterdam, Netherlands

Elewa AA, Mahdi H (1988) Some limnological studies on the Nile water Cairo, Egypt. Bull Nat Inst Oceanogr Fish ARE 14(2):141-152

El-Moselhy KM (2000) Accumulation of copper, cadmium and lead in some fish from the Gulf of Suez. Egypt J Aquat Biol Fish 4(3):235-249

El-Sherbini A, El-Moattassem M, Solterdijk H (1996) Water quality condition of the River Nile. In: Shady AM, El-Moattassem M,

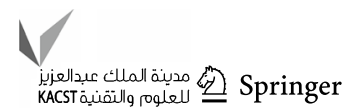


Abdel-Hafiz FA, Biswas AK (eds) Management and development of major Rivers. Oxford University, Calcutta

Eltholth M, Fornace K, Grace D, Rushton J, Hasler B (2015) Characterization of production, marketing and consumption patterns of farmed tilapia in the Nile Delta of Egypt. Food Policy 51:131-143

FAO (1992) Committee for inland fisheries of Africa; Report of the 3rd edn session of the working party on pollution and fisheries. Accra, Ghana. 25-29 Nov 1991. FAO Fisheries. Rep, No. 471. Rome, FAO, p 43

FAO (2013) Fisheries and Aquaculture Department has Published the Global Aquaculture Production Statistics for the Year 2011. http:// raisaquaculture.net/uploads/media../Aquaculture\%20production\% 202011.pdf

Foster IDL, Charlesworth SM (1996) Heavy metals in the hydrological cycle; trend and explanation. Hydrol Process 10:227-261

Ghannam HE, Talab AS (2009) Effect of pollution of water quality with heavy metals. Nat Sci 3:18-26

Ghannam HE, Talab AS, Jahin HS, Gaber SE (2014) Seasonal variation in physicochemical parameters and heavy metals in water of El-Bahr El-Pharaony Drain, El-Menoufia Governorate. Egypt Res J Environ Earth Sci 6(3):174-181

Goher ME, Farhat HI, Abdo MH, Salem GS (2014) Metal pollution assessment in the surface sediment of Lake Nasser, Egypt. Egypt J Aquat Res 40:213-224

Gorar FK, Keser RN, Akiel DS (2012) Radioactivity and heavy metal concentrations of some commercial fish. Chemosphere 187:56-361

Has-Schön E, Bogut I, Kralik G, Bogut S, Horvatić J et al (2008) Heavy metal concentration in fish tissues inhabiting waters of "Buško Blato" reservoar (Bosnia and Herzegovina). Environ Monit Assess 144(15-22):32

Ibrahim SA, Authman MM, Gaber HS, El-Kasheif MA (2013) Bioaccumulation of heavy metals and their histopathological impact on muscles of Clarias gariepinus from El-Rahawy drain, Egypt. Int J Environ Sci Eng 4:51-73

Kalfakakour V, Akrida-Demertzi K (2000) Transfer factors of heavy metals in aquatic organisms of different trophic levels. HTML publication 1:768-786

Kempster P, Van Vielt HR, Kuhn A (1997) The need for guidelines to bridge the gap between ideal drinking water and that quality which is practically achieve and acceptable. Water SA 23(2):163-167

Lamas S, Fernández JA, Aboal JR, Carballeira A (2007) Testing the use of juvenile Salmo trutta L. as biomonitors of heavy metal pollution in freshwater. Chemosphere 67:221-228

Mechea A, Martinsb MC, Lofranob BESN, Hardawaya CJ, Merchanta M, Verdadeb L (2010) Determination of heavy metals by inductively coupled plasma-optical emission spectrometry in fish from the Piracicaba River in southern Brazil. Microchem J 94(2):171-174

Nada Elshemy AM, Zeidan BA, Hassan AA (2016) Water quality assessment of Rosetta branch, Nile River, Egypt. Problem and
Solution, Tanta University, Egypt, Third International Environmental Forum, Environmental Pollution, pp 12-14

Olsen RD, Sommerfeld MR (1977) The physical-chemical limnology of desert reservior-Argone National Laboratory, aillinoic 60435. Hydrobiologia 53(2):117-129

Papagiannis I, Kagalou I, Leonardos J, Petridis D, Kalfakakou V (2004) Copper and zinc in four freshwater fish species from lake Pamvotis (Greece ). Environm Int 30(3):357-362

Pawelczyk A (2013) Assessment of health risk associated with persistent organic pollutants in water. Environ Monit Assess 185:479-508

Rashed MN (2001) Monitoring of environmental heavy metals in fish from Nasser Lake. Environ Int 27:27-33

Siliem TAE (1995) Primary productivity of the Nile in barrage area Menoufiya Egypt. J Agric Res 20(4):1687-1701

Talab AS, Goher ME, Ghannam HE, Abdo MH (2016) Chemical compositions and heavy metal contents of Oreochromis niloticus from the main irrigated canals (rayahs) of Nile Delta. Egypt J Aquatic Res 42(1):23-31

Tomlinson DL, Wilson JG, Harris CR, Jeffery DW (1980) Problems in the assessment of heavy metals level in estuaries and the formation of pollution index. Helgolander Meeresuntersuchngen 33:566-575

USEPA (2000) United State Environmental Protection Agency (USEPA) guidance for assessing chemical contaminant data for use in fish advisories, vol. 2 risk assessment and fish consumption limit, EPA/823/B-97/009, office of science and technology and office of water, Washington, DC, USA, 3rd edition, 2000

USEPA (2002) Region 9, Preliminary Remediation Goals, Region 9 PRGs Table 2002 Update, United States Environmental Protection Agency, 2002. http://waste.ky.gov/SFB/Documents/Regio n9PRGs.pdf

Vinodhini R, Narayanan M (2008) Bioaccumulation of heavy metals in organs of fresh water fish (Cyprinus carpio) Common carp. Int J Environ Sci Tech 5(2):179-182

Warren LA, Zimmerman AP (1994) Suspended particulate oxides and organic matter interactions in trace metal sorption reactions in a small urban river. Biogeochemistry 23:21-34

WHO (2011) World health organization evaluation of certain food additive and contaminants: seventy-third report of the joint FAO/ WHO expert committee on food additives, WHO technical report series 9860, WHO 2011

Zhao S, Feng C, Quan W, Chen X, Niu J, Shen Z (2012) Role of living environments in the accumulation characteristics of the heavy metals in fishes and crabs in the Yangtze River Estuary, China. Mar Pollut Bull 64:1163-1171

Publisher's Note Springer Nature remains neutral with regard to jurisdictional claims in published maps and institutional affiliations. 